\title{
Overtourism: A Literature Review to Assess Implications and Future Perspectives
}

\author{
Alessandro Capocchi * ${ }^{+}$, Cinzia Vallone, Mariarita Pierotti and Andrea Amaduzzi \\ Department of Business Economics and Law-DiSEADE, University of Milano Bicocca, Via Bicocca degli \\ Arcimboldi, 8, 20126 Milano, Italy; cinzia.vallone@unimib.it (C.V.); mariarita.pierotti@unimib.it (M.P.); \\ andrea.amaduzzi@unimib.it (A.A.) \\ * Correspondence: alessandro.capocchi@unimib.it; Tel.: +39-026-448-3191
}

Received: 12 May 2019; Accepted: 13 June 2019; Published: 15 June 2019

\begin{abstract}
Overtourism is an emerging concept facing the world's main tourist destinations. The growth that tourism has undergone in recent decades is of two different types. On the one hand, the development of new technologies and the creation of low-cost airline carriers have increased tourism levels, leading to growth even in emerging economies. On the other hand, uncontrolled demand alongside a concentration of tourism in particular destinations impact negatively both territories and local communities. The problems caused in some destinations by the increasing, ongoing growth in tourism have created the issue of "overtourism," which is assuming an increasing significance in the literature. This paper contributes to the literature by providing an exploratory study with which to better understand the origins of overtourism, its implications, and predicted future perspectives in respect to the issue. Examination of the new evidence presented here contributes to the expanding knowledge of particular problems of tourism development.
\end{abstract}

Keywords: overtourism; tourism development; literature review; sustainability; city destinations

\section{Introduction}

The growth of tourism [1] has been accompanied by the concentration of tourist flows to specific areas, causing crowding and problems with carrying capacity [2] and environmental sustainability [3], and by the "imitation effect" [4], whereby emerging economies mimic the tourist behavior of Western economies. Additionally, there are governance issues with respect to the resources of destination countries [5], relationships with airlines (primarily low-cost carriers), and technological developments, accompanied by environmental issues, with regard to increasing waste generation, water problems, and air pollution [6]. Regarding environmental issues, the debate on "anthropopressure" has also assumed importance [7].

Croce [8] predicts that, although shocks and crises will continue to negatively affect tourism's development, the long-term trend over the next decade will continue to show steady growth. This will result from increasing affluence in well-populated areas of the world feeding the demand for travel, and technology will continue to drive innovation [9]. Moreover, if global volumes of tourists increase, their distribution across regions of the world could change [10].

In this context, the term "overtourism" has begun to be used in the recent literature with particular regard to models of tourism development, some city destinations, and issues of sustainability [11-15].

According to the integrative review method followed by Perkumiene and Pranskuniené [16], the term overtourism does not represent a new phenomenon. Though this specific term has been intensively used for less than three years, the problem it concerns has been discussed in the scientific world over the last 40 years, and many world tourist destinations have long been dealing with this challenging phenomenon [16]. 
Following a specific and recent time period, the present paper takes stock of the term overtourism in order to define its parameters and theoretical framework, aiming to understand whether it can be considered a new phenomenon or merely a new marker to describe a phenomenon already studied in the literature. This is an important point to support future studies on the effects of expected growth in tourism between now and 2030 [17].

We organize the rest of the paper as follows. In the next section, we describe the study's method. We then provide a thorough review of the most salient literature in the study of "overtourism" and related fields. We conclude the paper with an analysis of the implications of the phenomenon, as well as with further considerations and research recommendations.

\section{Method}

This paper investigates mainstream overtourism, and, accordingly, we undertook a significant review of the principal international literature. We identified prior pertinent literature by searching Google Scholar, Social Sciences Research Network (SSRN), Scopus and other university library, e-journals and publishing databases. Then, we monitored the most important journals.

Methodologically, a literature review is considered to be the "Cinderella" of research [18], and the poor relation to primary research, or the dull but necessary prelude to a research report or proposal [19]. However, we believe the literature review to be very important, for several reasons: (a) new ideas may arise from others' studies, through synthesizing and summarizing previous sources [20]; (b) new theories can be built from the evidence discussed; and (c) new directions for future research can be suggested [21]. This is true in particular with regard to new mainstream or novel trends in a phenomenon-and consequently is the case of overtourism.

A literature review can also facilitate the use of best available evidence in daily practice by supplying answers to empirical questions. Such reviews are also an ideal first step into the world of publishing, as all the investigator needs is an initial research question, access to a literature database and some basic evaluation and writing skills. The recent increased appearance of the overtourism phenomenon in the literature places a duty on the academic community to establish what has been written up to this point on the subject and to define the reference perimeters in a rigorous manner. In addition, for the purpose of promoting future research work, this approach should be applied internationally.

According to Steward [18], a good review should be (a) comprehensive, (b) fully referenced, (c) selective, (d) relevant, (e) a synthesis of key themes and ideas, (f) balanced, (g) critical and (h) analytical. In a sentence, a literature review can provide a concise examination and discussion of evidence in a particular subject or area of investigation.

\subsection{Literature Review}

This section's elucidation of our study's research activity describes the following closely related and integrated steps: definition of the period under analysis; analysis of the bibliographic sources; identification of all relevant publications; selection of the main publications; analysis of the individual publications and comparisons between them; identification of key issues; analysis of the links between the various publications around the key issues; and considerations, recommendations and indications for future studies.

The period under analysis covers the years 2015 to 2019. Within this period, we identified and selected as main sources related to overtourism the publications listed in Table 1, following an interrogation of the Emerald database using the keywords "over-tourism" and "overtourism." The choice of the keywords was particularly sensitive because, for example, the use of the phrase "over tourism" would have elicited the identification of numerous publications that are not related to the subject of the present study. 
Table 1. Main sources.

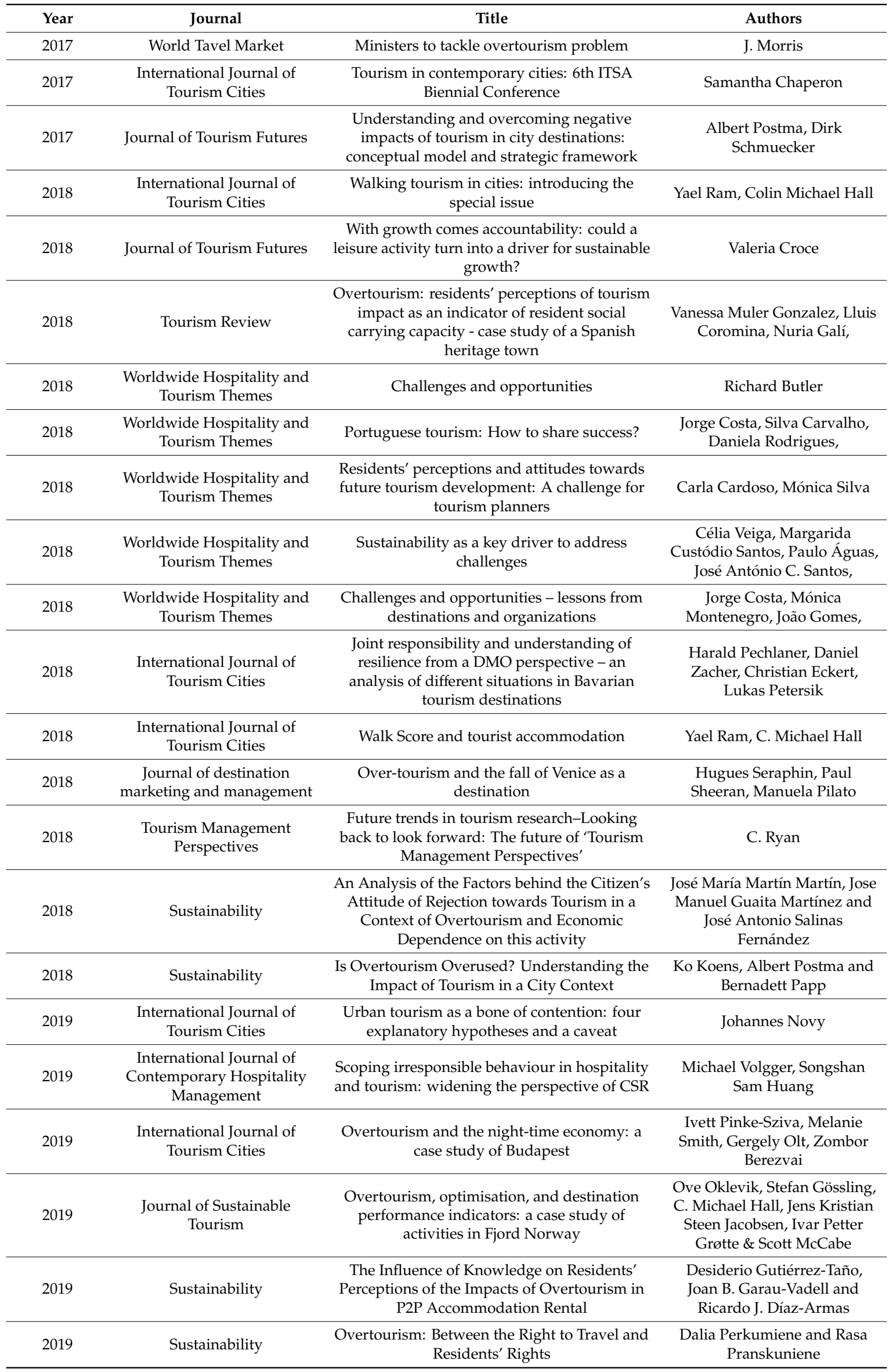


Table 1 shows for each publication the year, scientific journal, title, and authors.

Other significant publications are available on the Internet that, while they do not have an impact or quality ranking and in many cases are refractive toward practical and professionalizing areas, are nonetheless worthy of attention.

Table 2 presents the additional, online sources selected and considered germane within the overall scope of the research. For each publication, Table 2 shows the year, journal, title, and authors.

Table 2. Additional, unranked sources.

\begin{tabular}{|c|c|c|c|}
\hline Year & Journal & Title & Authors \\
\hline 2017 & $\begin{array}{c}\text { Responsible Tourism } \\
\text { Partnership Working Paper } 4 .\end{array}$ & The Challenge of Overtourism & Goodwin Harold \\
\hline 2017 & $\begin{array}{l}\text { Ovidius" University Annals, } \\
\text { Economic Sciences Series } \\
\text { Volume XVII, Issue } 2 .\end{array}$ & $\begin{array}{l}\text { Over-Tourism and Anti-Tourist } \\
\text { Sentiment: An Exploratory } \\
\text { Analysis and Discussion }\end{array}$ & Papathanassis Alexis \\
\hline 2018 & $\begin{array}{l}\text { Investigaciones } \\
\text { Regionales-Journal of } \\
\text { Regional Research }\end{array}$ & $\begin{array}{l}\text { Venice: the problem of } \\
\text { overtourism and the impact of } \\
\text { cruises }\end{array}$ & Gonzalez A. T. \\
\hline 2018 & $\begin{array}{l}\text { Revista de Turismo y } \\
\text { Patrimonio Cultural }\end{array}$ & $\begin{array}{l}\text { Overtourism, malestar social y } \\
\text { turismofobia. Un debate } \\
\text { controvertido }\end{array}$ & Claudio Milano \\
\hline 2018 & $\begin{array}{c}\text { RESPONSIBLE HOSPITALITY: } \\
\text { INCLUSIVE, ACTIVE, } \\
\text { GREEN_M. Gorenak \& A. } \\
\text { Trdina (eds.) }\end{array}$ & $\begin{array}{l}\text { CHAPTER 13-Overtourism } \\
\text { and the green policy of } \\
\text { Slovenian Tourism }\end{array}$ & $\begin{array}{c}\text { Marjetka Rangus, Biliana } \\
\text { Bozinovski and Bostjan } \\
\text { Brumen }\end{array}$ \\
\hline 2019 & $\begin{array}{c}\text { Heidelberg } \\
\text { University-MPRA Paper No. } \\
92213\end{array}$ & $\begin{array}{c}\text { From overtourism to } \\
\text { sustainability: A research } \\
\text { agenda for qualitative tourism } \\
\text { development in the Adriatic }\end{array}$ & Maximilian Benner \\
\hline
\end{tabular}

The publications indicated in Tables 1 and 2 were rigorously scrutinized, using comparative analysis, in order to investigate the following key issues: (a) the origins of the overtourism phenomenon, (b) the implications of the phenomenon and (c) future perspectives in relation to phenomenon. The comparative analysis was also conducted in order to identify links between the various publications and the occurrence of cross-referencing.

\subsection{Cross-References and Keywords}

Before analyzing the contents of the publications in detail, we checked for cross-references between the different articles and the repeated use of keywords. With regard to cross-references, Table 3 demonstrates how the debate in the literature is still in its infancy, and correspondingly how the present study's relatively short period of analysis does not capture a repeated use of particular references in the literature of that time period. 
Table 3. Cross-references.

\begin{tabular}{|c|c|c|c|}
\hline Author & Year & Cross-Reference Quotes & Year \\
\hline $\begin{array}{l}\text { Dalia Perkumiene and Rasa } \\
\text { Pranskuniene }\end{array}$ & 2019 & $\begin{array}{c}\text { Ram, Y.; Hall, C.M. } \\
\text { Martín, J.M.; Guaita Martínez, J.M.; Salinas Fernández, J.A } \\
\text { Albert Postma, Dirk Schmuecker } \\
\text { Vanessa Muler Gonzalez, Lluis Coromina, Nuria Galí, } \\
\text { Papathanassis, A } \\
\text { Koens, K.; Postma, A.; Papp, B. } \\
\text { Freytag, T.; Bauder, M. } \\
\text { Goodwin H. }\end{array}$ & $\begin{array}{l}2018 \\
2018 \\
2017 \\
2018 \\
2018 \\
2018 \\
2018 \\
2017\end{array}$ \\
\hline $\begin{array}{l}\text { Desiderio Gutiérrez-Taño, Joan B. } \\
\text { Garau-Vadell and Ricardo J. } \\
\text { Díaz-Armas }\end{array}$ & 2019 & No Cross-Ref & - \\
\hline $\begin{array}{c}\text { Michael Volgger, Songshan Sam } \\
\text { Huang }\end{array}$ & 2019 & No Cross-Ref & - \\
\hline $\begin{array}{l}\text { José María Martín Martín, Jose } \\
\text { Manuel Guaita Martínez and José } \\
\text { Antonio Salinas Fernández }\end{array}$ & 2018 & No Cross-Ref & - \\
\hline $\begin{array}{l}\text { Ko Koens, Albert Postma and } \\
\text { Bernadett Papp }\end{array}$ & 2018 & $\begin{array}{l}\text { Vanessa Muler Gonzalez, Lluis Coromina, Nuria Galí, } \\
\text { Hugues Seraphin, Paul Sheeran, Manuela Pilato }\end{array}$ & $\begin{array}{l}2018 \\
2018\end{array}$ \\
\hline $\begin{array}{l}\text { Jorge Costa, Mónica Montenegro, João } \\
\text { Gomes, }\end{array}$ & 2018 & No Cross-Ref & - \\
\hline $\begin{array}{c}\text { Célia Veiga, Margarida Custódio } \\
\text { Santos, Paulo Águas, José António C. } \\
\text { Santos, }\end{array}$ & 2018 & $\begin{array}{c}\text { J. Morris } \\
\text { Albert Postma, Dirk Schmuecker } \\
\text { Hugues Seraphin, Paul Sheeran, Manuela Pilato }\end{array}$ & $\begin{array}{l}2017 \\
2017 \\
2018\end{array}$ \\
\hline Carla Cardoso, Mónica Silva & 2018 & Albert Postma, Dirk Schmuecker & 2017 \\
\hline $\begin{array}{l}\text { Jorge Costa, Silva Carvalho, Daniela } \\
\text { Rodrigues, }\end{array}$ & 2018 & No Cross-Ref & - \\
\hline Richard Butler & 2018 & No Cross-Ref & - \\
\hline $\begin{array}{l}\text { Vanessa Muler Gonzalez, Lluis } \\
\text { Coromina, Nuria Galí, }\end{array}$ & 2018 & No Cross-Ref & - \\
\hline Valeria Croce & 2018 & No Cross-Ref & - \\
\hline $\begin{array}{l}\text { Hugues Seraphin, Paul Sheeran, } \\
\text { Manuela Pilato }\end{array}$ & 2018 & No Cross-Ref & - \\
\hline Yael Ram, Colin Michael Hall & 2018 & No Cross-Ref & - \\
\hline Albert Postma, Dirk Schmuecker & 2017 & No Cross-Ref & - \\
\hline Samantha Chaperon & 2017 & No Cross-Ref & - \\
\hline
\end{tabular}

For each publication Table 3 shows the cross-references, including the name of the cited authors and the year of their publication.

As can be seen in Table 3, Muler Gonzalez et al. [21] and Seraphin et al. [22] are cited twice while Postma and Schmuecker [23] are cited three times by authors who have published in different journals. Overall, the observable lack of cross-references can be explained by the relatively recent appearance of the phenomenon of overtourism, as well as by our study's narrow period of analysis.

Next, an analysis of keywords in the selected literature allowed us to identify the use of a total of 68 keywords. These are listed alphabetically in Table 4, accompanied by the frequency of each keyword's use in the examined publications.

Among the keywords identified, those that demonstrated a higher frequency of use were overtourism, which featured six times; tourism, which was found four times; sustainability, also four times; and city destination, which was found twice.

Evaluating keywords in this way allowed us to comprehend the different perspectives applied and discussed in the selected papers. The main theme that emerged from this stage of analysis concerned sustainability, as emphasized through the use of the following keywords: corporate social irresponsibility, corporate social responsibility, destination social responsibility, irresponsible, social 
sustainability, sustainable growth and sustainable tourism. The second issue that was distinguishable concerned the impact that tourism has, as highlighted by the following keywords: tourism impact studies, tourism impact, impacts, impact perception and economic impacts. The third issue related to the effects of technology, through the following keywords: new technologies and technologies.

Table 4. Keywords.

\begin{tabular}{cccc}
\hline Keywords & Frequency & Keywords & Frequency \\
\hline Ambidextrous management & 1 & Over-tourism & 1 \\
Best practices in tourism & 1 & Overtourism & 6 \\
Carrying capacity & 1 & P2P Accommodation & 1 \\
Catalonia & 1 & Perceptions & 1 \\
City tourism & 2 & PEST analysis & 1 \\
Climate Change & 1 & Politics & 1 \\
Conflict mechanisms & 1 & Porto & 1 \\
Corporate Social Irresponsability & 1 & Portugal & 1 \\
Corporate Social Responsability & 1 & Resident's attitudes & 1 \\
Degrowth & 1 & Resident's Rights & 1 \\
Destination social responsability & 1 & Residents & 1 \\
Destinations & 1 & Right to travel & 1 \\
Deviant behaviour & 1 & Sharing economy & 1 \\
Economic impacts & 1 & Social exchange theory & 1 \\
Experience & 1 & Social sustainability & 1 \\
Forecast & 1 & Spain & 1 \\
Gender & 1 & Sustainability & 4 \\
Growth drivers & 1 & Sustainable growth & 1 \\
Host-guest relations & 1 & Sustainable Tourism & 3 \\
Impact perception & 1 & Technologies & 1 \\
Impacts & 2 & Tourism & 4 \\
International tourism & 1 & Tourism impact & 1 \\
Irresponsible & 1 & Tourism impact studies & 1 \\
Knowledge & 1 & Tourismphobia & 1 \\
Long-term forecasts & 1 & Trexit & 1 \\
New technologies & 1 & Venice & 1 \\
Opportunities & 1 & & \\
\hline & & & \\
\hline
\end{tabular}

\section{Results}

\subsection{Overtourism: Preliminary Definitions and Use of the Term}

The term "overtourism" has been used to describe both a new or recent phenomenon closely linked to the development that tourism has had over recent decades, as well as the growing impact that tourism has generated in terms of the concentration of flows on several main tourist destinations all around the world and issues related to the governance of the tourism phenomenon.

Overtourism is still at the early stages of being defined and currently lacks a standardized, recognized characterization. In attempting to define the parameters within which to insert the phenomenon, we chose to consider three connected areas: (1) growth, (2) concentration and (3) governance (see Figure 1). The first-growth concerns the increased importance assumed by tourism in the past few decades worldwide. The growth of tourism has been partly accompanied by the massification of tourist flows and by the "imitation effect" of emerging economies in respect to the tourist behavior of Western economies. Second, the growth and massification of tourist flows have determined the concentration of arrivals in the main destinations, in turn bringing about crowding, carrying capacity and environmental sustainability concerns. Last but not least, the issue of governance was considered with regard to the resources of the territories and to relations with the airline carriers-low-cost in primis-and with technologies. 


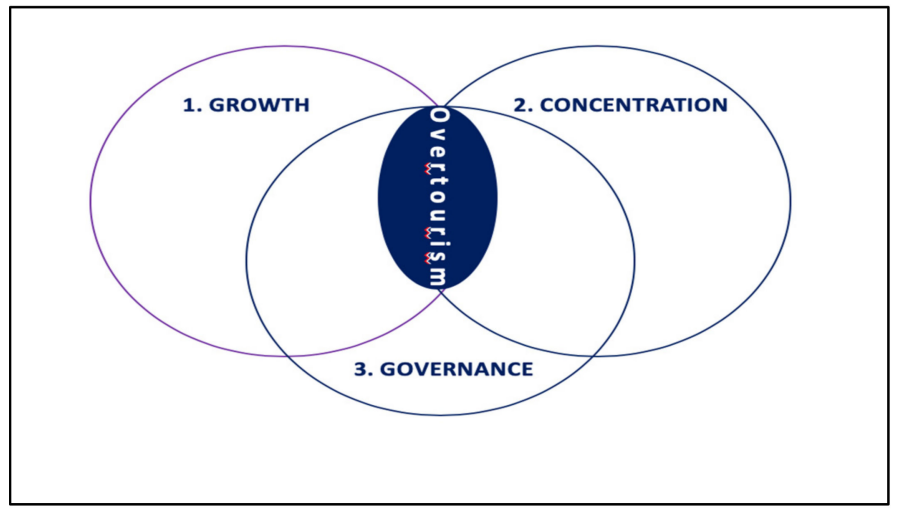

Figure 1. Overtourism: Growth-Concentration-Governance.

Martin Selby of Coventry University, England, in 2016 observed [11] that major tourist cities such as London, Paris and Bangkok continued to grow even if, during the focal period, the issues of security and political instability were significant. Selby also introduced the term "overtourism," linking it to (a) congestion and failing infrastructures and (b) increased resistance toward and protest against tourism among marginalized and displaced inhabitants. Furthermore, the author posited that this phenomenon would become increasingly important in the future, as it can be linked to the themes of the relationship between tourists and residents and new technologies. In fact, it is expected that new technologies will have a positive impact on the relationship between tourism and the focal territory.

Goodwin [12] explains the concept of overtourism as a situation in which either local people or tourists feel that a place is simply over-visited and is consequentially changing its character, losing its authenticity (mainly for tourists) and causing irritation and annoyance (primarily for residents). Additionally, Goodwin notes that, at the World Travel Market in 2017, the World Tourism Organization's (UNWTO) Ministers' Summit addressed the issue of overtourism.

We found that overtourism has emerged rapidly as a concept. The term is capable of drawing immediate recognition, particularly as a label that enables people, whether visitors or locals, to voice their concerns about too much tourism. The recent growth in references to the phenomenon was also confirmed by our study's analysis of it using Google Trends, as depicted in Figure 2.

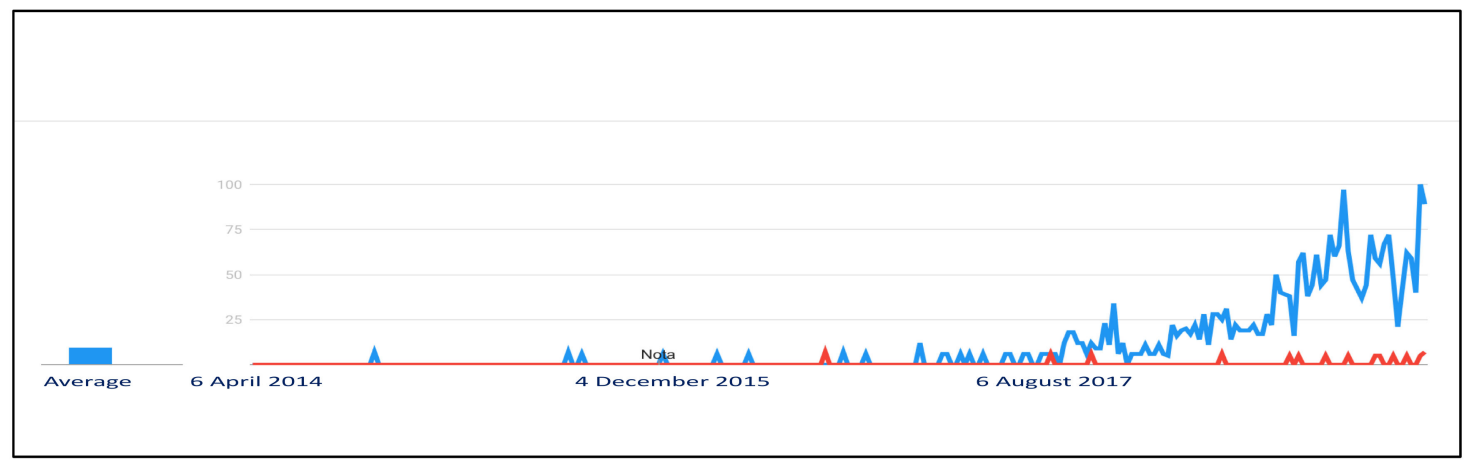

Figure 2. Google Trends: Use of "Overtourism" and "Over-tourism.".

Figure 2 shows the Google Trends tracking of the word "overtourism" in blue and of the word "over-tourism" in red in the period from April 2014 to the end of 2018. It is easy to see how searches on Google of the two terms have taken on a greater significance since 2017, which also confirms the trends observed in our analysis of primary and secondary sources. 


\subsection{Overtourism in the Literature}

\subsubsection{Origin of the Phenomenon}

In the academic community, the issue of overtourism has become increasingly important in recent years. The marketability and accessibility of the term appear to be at least partially responsible for its entry into academia, rather than its explanatory value-as exemplified by a recent paper that uses "overtourism" in its title, yet does not mention it in the main text at all [13]. This new concept can actually be considered "blurred" because it is not well defined, lacks clarity and is very difficult to make operational [24]. As such, it may often be used as a vehicle for legitimizing existing ideas [14,15].

More specifically, in the 1960s, authors discussed the ways in which tourism negatively affected destinations, introducing to the international debate the common thread concerning excessive tourism concentrations harming the local environment and provoking negative attitudes among residents in urban and rural areas [6] In the 1980s, discussions regarding destinations' carrying capacity advanced this debate [25]. The idea was to find the limit on the number of tourists who could visit without serious negative consequences, which may be higher or lower depending on the physical characteristics of the destination and residents' attitude, loyalty and pride [25]. As Koens et al. observed in 1979, Rosenow and Pulsipher had coined the term "visitor overkill." Subsequently, other investigatory perspectives were also introduced, all of which were connected with the themes of environmental sustainability and the risks linked to tourismphobia $[6,26]$.

From the 1990s onwards, the debate has shifted toward a more restrictive perspective, placing greater emphasis on the responsibility of the sector's actors and individual tourists [6]. For these reasons, Koens et al. [6] note that overtourism only became important as an alternative to the Spanish term "Turismofobia" at the end of 2016. Several contributions to the literature have covered the tourist function as a socio-economic activity aimed at serving tourists and performed by a location or area in the national economy system $[27,28]$, following the tourist function indicators recognized in the subject literature: Defert [27], Charvat [28], and density [29]. This approach is important to link theory and practice for assessing the scale of tourist traffic and the density of accommodation facilities in a given area [30-32], where higher values of these indicators simultaneously indicate a better-developed tourist function and stronger environmental pressure in a focal region.

Koens et al. [6] observe that the term overtourism largely arose from media discourses without much theoretical grounding. The issue it describes-an excessive negative impact of tourism on the host communities and/or the natural environment- - has been a critical concern within academia for many years, though. While it goes beyond the scope of this paper to provide a full overview of all prior work on the subject, it would be useful to highlight a number of key insights. It is here notable too that a large part of the debate regarding the overtourism issue has developed outside of the academic field of tourism.

The UNWTO [33] defines overtourism as the impact of tourism on a destination, or parts thereof, that excessively influences the perceived quality of life of its citizens and/or the quality of visitors' experiences in a negative way. In the UNWTO report [33], it is further described as rapid urbanization, or the growth of the tourism sector led by economic development, lower transport costs, travel facilitation and a growing middle class in advanced and emerging economies that have made cities increasingly popular destinations for business and leisure tourists. In sum, it is postulated that the absence of good management and the presence of uncontrolled development are the main reasons for the overtourism phenomenon. The UNWTO report [33] clearly states that tourism must be developed and managed in a sustainable manner for both visitors and local communities, as tourism is an opportunity for communities and their people to share its benefits, which is why relations between the sector and the communities need to be strengthened.

The UNWTO approach is similar in its representation of the issue of overtourism compared to earlier conceptualizations. However, while only a limited section of the prior literature concerns itself with overtourism, and much of it is explorative in nature, some differences can still be observed. 
For example, one area of the literature focuses its attention on the relationship between tourism, the wider urban context and the political aspects of excessive tourism growth $[34,35]$. Within such analysis, the main problems are related to the interaction between tourism and urban change [36].

Other literature comes to the theme of overtourism from the starting point of sustainability, from the development of new technologies and from the massification of tourism. In all cases, the phenomenon is characterized by the exclusion of or conflict with residents and other local stakeholders and the touristization and museification of popular tourist destinations. In addressing issues of over-organization, the authors of these publications highlight the need for regulation and leadership of the territorial government. This perceived need is in stark contrast to the more autonomous and self-governing perspectives that have dominated discourses on tourism for several decades previously, although there is still little clarification as to how new political arrangements could be made to work in practice.

Within this perspective, Koens et al. [6] state that overtourism can be considered mainly as a social issue, because (a) it is not a recent phenomenon, (b) it is not the same as mass tourism, (c) its impacts are not city-wide, (d) it is not only a tourism problem, (e) it is not possible to solve it simply by implementing new technologies, (f) there is no one-size-fits-all solution for overtourism and $(\mathrm{g})$ it is not just an issue in the focal city destination. Specifically, Koens et al. [6] (p. 2) define overtourism as "an excessive negative impact of tourism on the host communities and/or natural environment." The authors observe too that the term emerged for the first time in public debate regarding the phenomena discussed in the academic literature during the 1960s on the negative effects of tourism on destinations.

Similarly, Benner [37] (pp. 3-4) finds that, "on a theoretical level, the recent debate regarding overtourism and, more generally, concerning the cultural, social and environmental sustainability deficits of permanently growing mass tourism is not new. What is new, though, is the level of awareness of the possibly damaging effects of the permanent quantitative growth of mass tourism." This is a relevant research strand that can be advanced to support policymakers in respect to future strategies. For Benner ([37] (p. 6)), the potential risks connected to overtourism could include (a) increasing costs of living; (b) real estate speculation; (c) congestion of transport infrastructures; (d) the loss of sense of belonging of local residents with the place; (e) the loss of a destination's authentic character or (f) the privatization of spaces ([6] (pp. 2-4), [22] (p. 375)).

Benner [37] also observes how the origin of the debate that currently affects the overtourism phenomenon can be related to the discussions on the limits to growth in industrial development that first started in 1972, with the publication of the Club of Rome's seminal report [38]. "Looking back to past decades since the early 1970s, it seems reasonable to infer that former consensus on the desirability of quantitative, resource-intense and therefore unsustainable growth in manufacturing has broken down in the wake of the 'limits to growth' debate" ([37] (p. 6)). For Benner ([37] (pp. 6-7)), "the current public debate on overtourism could play a similar role to that of the Club of Rome's 1972 report and the discussions that commenced in its aftermath. Certainly, in leading tourist destinations marked by the harmful effects of overtourism, any previous consensus on the desirability of permanent quantitative tourism growth for the sake of maximizing the economic benefits of tourism without fully considering the possibly damaging side effects on the social, cultural and ecological environments has come under intense pressure from civil society and local populations. To safeguard the economic benefits of tourism, shifting the focus of tourism development toward qualitative growth and drawing on market segments with higher localized value added and lower social, cultural and environmental impact will be necessary to balance the economic effects desired, such as generating localized value added, tax revenues, and employment, with the social, cultural and environmental sustainability that is indispensable in the long term". 


\subsubsection{Implications of Overtourism}

The overtourism phenomenon assumes further significance as recent increases of tourism in some destinations is being associated with a combination of heightened accessibility involving low-cost carriers and declining airfares [39] and the global relevance of social media and other evaluation platforms in streamlining opinion and influencing demand, as well as new and inexpensive accommodation offers through Airbnb and other online platforms [40]. All of these changes are important in terms of visitor composition, length of stay, place of stay, tourist expectations and resident perceptions, especially in circumstances in which, recently, Airbnb has caused severe disruptions in residential housing supplies [41]. Additionally, such changes have resulted in more critical perspectives on the desirability and quality of growth by some destination stakeholders, including businesses and residents, as well as tourists [42].

In this framework, according to Veiga and colleagues [43], overtourism can be said to occur when too many visitors or tourists arrive in a particular place at the same time $[44,45]$. Thus, for Veiga et al. [43], overtourism is strictly connected to the problem of mass tourism saturation that exists in many destinations worldwide, diminishing the quality of life of residents and creating negative experiences for tourists. It is argued, therefore, that overtourism has only become an important media topic in the last decade because of criticism and demonstrations led by social movements in various European cities [46,47]. Prior studies describe how, in some cases, such as Barcelona and Venice, extremely aggressive positions have been taken against tourism, introducing the so-called "anti-tourism" or "tourismphobia" phenomena $[48,49]$. The rise of anti-tourism movements has become, for some authors, a notorious problem that is a consequence of uncontrolled growth in the number of visitors [41]. Furthermore, the phenomenon of overtourism is theorized to have come about largely because of a combination of three main factors in particularly attractive but limited urban spaces: large cruise ships, low-cost airlines and new platforms for tourist rental accommodation, especially Airbnb [23].

Accordingly, given this context and with widespread media reporting on overtourism, overcrowding and anti-tourist sentiment, destination-marketing organizations, particularly in Europe, have begun to openly and critically discuss the desirability of continued growth-focused perspectives for tourism. Oklevik et al. [49] analyze overtourism with respect to the crowding effect, observing how crowding as an issue for destinations has been a recurrent topic in tourism research since the early 1970s [50,51]. Butler [52] observes how it is clear that the success in growing tourism globally, both domestically and internationally, has resulted in some destinations being unable to handle such increased numbers at a satisfactory level and in a manner that does not arouse opposition from permanent residents of such destinations. As regards the current issues of tourism, the term overtourism is increasingly being applied to a range of locations from Venice to Barcelona and the Isle of Skye in Scotland to Boracay in the Philippines. Importantly, Butler [52] distinguishes between the concept of overtourism and that of over-crowding, clarifying that the former is not the same as over-crowding or busy destinations, but instead represents a situation in which numbers of visitors overload the services and facilities available and also become a serious inconvenience for permanent residents of such locations.

Volgger and Huang [53] note how, in the cases of recent residents' protests in European tourism destinations covered under the "overtourism" headline [54,55], the identified culprits for the perceived acceleration in tourism development include short-term rental providers such as Airbnb, budget airlines and cruise ship operators [56,57].

Croce [8] posits that, in relation to tourism, it may become important to implement a new approach to economic development that puts the valorization of intangibles, such as the conservation, preservation and protection of cultures or the environment, at the heart of economic development. According to this contention, natural and cultural resources are the lifeblood of tourism, and, while tourism can contribute toward the protection of the natural and cultural heritage of a destination, not least securing its value, visibility and profitability, tourism can also become its main cause of 
disruption. In this line of thinking, sustainability concerning social and environmental pillars is probably the most manifest paradox of this global sector, wherein tourism is called upon to react and to transform challenges into new opportunities in order to stop the negative impact of the overtourism.

Oklevik et al. [49] have also discussed how, in recent years, the continued rapid growth in tourist arrivals in popular destinations and the associated problems of crowding and localized inflation and pressure on residential housing have stimulated substantial public debates regarding the desirability of a tourism system based on a growth model. Thus, crowding or overtourism has become an important issue for residents as well as tourists in several destinations, including New York City, Amsterdam, Reykjavik, the Isle of Skye, the Koh Phi Phi Islands of Thailand and the Palawan archipelagic province of the Philippines.

\subsubsection{Implications of Overtourism in City Destinations}

As well as Butler's research, in the literature, there are several other studies concerning the overtourism of specific destinations all around the world. Papathanassis [58], following the generic product life-cycle concept adapted by Butler [59] in relation to tourism destinations, investigates the evolution and implications of tourism in several cases. He critically discusses the issue of over-tourism and the resulting anti-tourism sentiments with the purpose of setting a frame for a more constructive discussion and effective measures. Papathanassis observes how the externalities of tourism have become increasingly visible over the last decade, in particular with regard to some famous European destinations: Venice, Dubrovnik, Santorini, Barcelona and Amsterdam. These reactions, in conjunction with the corresponding press attention, have led to a variety of proposed measures by tourism stakeholders and decision-makers aimed at controlling tourism development and restricting incoming tourism. At the same time, the term "excessive tourism" implies a series of developmental externalities linked to tourism and is therefore a complex and multifaceted topic, as well as one that is neither new nor poorly researched: excessive tourism, for Papathanassis, mainly concerns a lack of awareness of the meaning that the tourism can take in respect to particular territories, and therefore it is important that policymakers pay attention not only to the management of tourist flows but also to the processes of educating tourists.

Costa et al. [60] consider how the major European cities—such as Paris, London and Barcelona-are currently evaluating overtourism. The introduction of low-cost flights has brought about a revolution through an unprecedented increase in international travel. For this reason, in its annual trends review "Tourism in 2018," the Institute for Tourism Planning and Development (IPDT) analyzes the theme of overtourism by looking at Amsterdam, Barcelona, Dubrovnik, Iceland, London, Majorca, Paris, Prague and Venice, identified as the main sites near the point of overtourism, and trying to understand if overtourism has led to the loss of inhabitants in these urban centers [61].

The role of the city destination is crucial in the analysis of the phenomenon all around the world. Following this research strand, Chaperon [62] finds that city destinations are more central to contemporary tourism, as, according to the United Nations, more than $54 \%$ of the world's population live in urban environments and this figure is projected to grow to $60 \%$ by 2030 [63]. The rapid growth of global cities has been mirrored by the growth in tourism to these destinations, and understanding this phenomenon is vital in ensuring the developments associated with urban tourism are sustainable and that local urban populations both benefit from the industry and support it [64]. Many cities represent the gateway for tourists visiting a country, and the world's most important tourism cities are destinations in their own right. Secondary or intermediate cities [65] in a country are also beginning to develop their offer and promote themselves as tourist destinations. This approach is usually linked to a new government strategy oriented toward moving tourist flows away from the primary cities in an attempt to reduce problems associated with overtourism, while simultaneously redistributing the benefits that tourism brings. For example, the U.K. Government's tourism policy in 2011 aimed to use the hosting of the Olympic Games 2012 as a way of creating and promoting alternative destinations to equal London $[66,67]$. 
In the analysis carried out by the academic community, some city destinations have become so characterized by overtourism that terms such as "Venice Syndrome" are used to allude to the phenomena and the depopulation of city centers [68]. The case of Venice is relevant, as a combination of certain factors has resulted in a pronounced rejection of tourism: the large number of arrivals (more than 10 million every year) is cited as being one of the main causes, given that the historic quarter holds around 55,000 inhabitants. This issue has caused housing prices to increase greatly, making it the most expensive city in Italy at the present time, and this factor only adds to the lack of housing derived from the substitution of residential rentals with tourist ones advertised via online platforms like Airbnb, resulting in a reduction of the permanent population of the city. "Due to the ecological sensitivity of the lagoon, the old city and its immediate surroundings represent an ecosystem very much endangered not only by increasing crowds of visitors but also by the type of tourism prevalent-notably, cruise ships crossing the lagoon" ([22], [37] (p. 5)).

Gonzalez [69] also analyzes the current problem of tourism in Venice and the tragic transformation that the city has experienced, from its inscription to the UNESCO World Heritage List in 1987 to the List of World Heritage in Danger in 2016. Moreover, Venice can be considered as a typical example, albeit on a smaller scale, reflecting the issues of a large number of cities worldwide. In particular, though, the case of Venice is affected by the problem of the cruises, which has a huge impact on the environment, as they damage its basic constructive structure and the ecosystem, and yet do not generate a prolonged wealth in the city. Venice receives 66,000 tourists a day, of which two and a half million arrive on cruises each year [70]. In 2009, the number of passengers who disembarked in Venice from cruises was 1,420,490, while, in 2010, it was 1,598,616-an increase of $12 \%$. The crossing of the cruises by Bacino San Marco was at 1258 in 2010. Cruise passengers comprise a high number of visitors per year, all crowding in the same space during a specific time slot and turning the city into a kitsch postcard of itself [71]. Cruises are considered to be a problem more widely because they impose a great (mass) tourist impact instantly; a space issue with little monetary compensation. Locally, there are few benefits, even if the cruise passenger benefits from the experience of visiting the city just for a few hours. Lots of cities suffer such a spatial impact, altering their context and their routine. In Venice, where space is even more limited, the presence of these great ships (and tourists) is immediately perceptible. Gonzalez [69], following Settis [72], observed how:

Cities can die by three different ways: when they are destructed by an enemy, when a new civilization set up by force, expelling the natives and their gods and thirdly, when the inhabitants themselves lose their memory and become foreigners in their own city. If we look around, to our landscapes, to our cities, to be abandoned to beauty is not enough, is not even enough to ask beauty for a miraculous salvation [...]. Beauty will save nothing and no one, if even we are not able to save beauty. Neither culture, history, memory, economy [...] life. [72] (p. 3).

Linked to the case of Venice, Veiga et al. [43] chronicle how overtourism may come about through two main phenomena: (1) the impact of cruise tourism on sustainability and the environment and (2) the fact that the growing demand for accommodation in residential areas has had an adverse impact on social sustainability [45]. In their analysis, the authors contribute to the doctrinal debate explaining how companies and destinations can mitigate the impacts of climate change and the phenomenon of overtourism, identifying a number of good practices carried out by destination managers and companies in different tourism sectors.

"The Croatian coastal city of Dubrovnik is another salient example pertaining to the damaging effects and problems related to overtourism on the Adriatic Sea. Due to the popularity of its old town, the boom of cruise tourism, and the impact of the widely known television series Game of Thrones being shot partly in Dubrovnik, a quantitative growth in tourism has led to overcrowding and to what Panayiotopoulos and Pisano [73] (p. 7) call an "overtourism dystopia" related to "the paradox of tourism risking to destroy the very thing that tourists come to see." Policy responses have included attempts to limit the number of tourists admitted to the city and to restrict the capacity of cruise ships permitted to call at the city's port" ([37] (pp. 5-6)) [73]. 
Rangus et al. [74], analyzing the case of the "green policy" in Slovenia, posit that the term "over-tourism" is related to a significant aspect of sustainable tourism. Over-tourism here is related to not only crowded destinations at the environmental limits of their capacities but also conflicts among tourists and local residents in the hosting communities. Researchers have observed how, in many destinations, the local population has little or no say regarding tourism development, which may lead to local people finding their own homes no longer suitable for living their everyday lives, lacking privacy, a sense of community and any influence on the decision-making process [75].

Postma and Schmuecker [23], who studied Hamburg, link the overtourism issue to the crowding phenomenon, indicating several potential areas of conflicts. For these authors, the specific fields of conflict have to be identified because they will differ in their importance from city to city and from destination to destination, but may include cruise tourists flooding a city's center, "beer bikes," and the rise of housing prices because of an increasing numbers of Airbnb rentals. They observe how, typically, public discussion about "visitor pressure" or "overtourism" starts with one publicly visible field of conflict, and a conceptual model can help to embed this problem into a larger framework and thereby prevent it from being discussed in isolation. In other cases, cities should aim to assess their current status and vulnerability to unbalanced tourism development. Within such cases, too, the authors' conceptual model may provide support in obtaining a more holistic view as regards the underlying issue.

Cardoso and Silva [76] present the results of a quantitative survey of 140 residents of the city of Porto. In this research, there are perceived to be several negative effects related to crowding, inflation and other nuisances that are often attributed to the massive growth of tourist numbers. Further to the identification of such issues, the increasing manifestation of concepts such as tourismphobia, overtourism, tourist gentrification or simply visitor pressure is noted and investigated. For Costa et al. [77], analyzing the case of Portugal, overtourism is indicated as a future important challenge alongside sustainability, the quality of tourism offers and human resources. Destinations require a clear strategy based on sustainable principles in order to maintain and expand the benefits of tourism. Such a strategy will be very important as well in keeping under control the waves of popularity resulting from the arrival of low-cost airlines to destinations, and in avoiding massification and, ultimately, the trivialization of key tourism spots. This is the reason it is important to rethink destination strategies, and, rather than preventing tourists from arriving, encourage them to diversify destinations and activities, reduce seasonality and, above all, meet the needs of local communities.

Pforr et al. [78], without using the word "overtourism", investigate the organizational transformation of regional tourism in Western Australia in order to make it fit for the future, while Gonzalez et al. [21] assess the value of impact perceptions as an indicator of social carrying capacity in the heritage town of Besalú in Spain.

\subsection{Future Perspectives}

The issue of overtourism will become increasingly important in future studies relating to tourism. More specifically, such studies will likely not focus on the causes of the phenomenon, but instead on the destinations that progressively deal with the problems, the associated implications of the phenomenon and the possible solutions that could be adopted. Benner ([37] (p. 7)) discusses overtourism as "a complex and multilayered phenomenon specific to the context at hand [8], countering that it is necessarily a multidimensional effort that can be analyzed along the dimensions of policies, organizations, institutions, and behavior." Such a multidimensional effort can be achieved through community engagement, congestion management, reduction of seasonality, careful planning that respects the limits of capacity and the specificities of the destination, as well as product diversification.

Accordingly, the tourism-carrying capacity of a destination-defined by the UNWTO as "the maximum number of people that may visit a tourist destination at the same time, without causing destruction of the physical, economic, and sociocultural environment and an unacceptable decrease in the quality of visitors' satisfaction" [18] (p. 3) -is a key challenge for tourism developers and managers 
alike. The World Economic Forum [79], comparing resident populations to overnight visitors per year in order to highlight crowding pressure (1:360 in Venice, 1:33 in Dubrovnik, 1:8 in Paris), suggests that destinations will increasingly turn to caps, citing Santorini (Greece) and Cinque Terre (Italy) as significant examples. In Croatia, for example, the number of international tourist arrivals rose from 1.485 million in 1995 to 15.593 million in 2017. This trend shows the difficulty of constructing infrastructure at sufficient scale and speed to match the growth in arrivals. Without adequate instruments and appropriate policies, this will result in the phenomenon of overtourism.

Meanwhile, in response to crowding problems, the UNWTO has called for destinations to better manage tourism, albeit without questioning the underlying assumption of a continuation in growth strategy. The supposition of the World Travel Market's "Minister's Summit," co-organized by the UNWTO in London in November 2017, concerning overtourism reflects this perspective: growth is not the enemy, it is how we manage it [80].

Within this common framework, according to Veiga et al. [43], in a bid to address the problem of overtourism, different destinations have developed distinct approaches, ranging from legal measures to limit or prohibit the expansion of tourism in already-congested areas and reduce the impact on residents' access to housing facilities to the adoption of technologies that monitor and manage tourism flows. The latter new technologies are also used to communicate with tourists in real time in order to provide information and suggest alternative attractions. Likewise, another practice consists of redirecting tourism flows to areas usually not visited by tourists, such as street art tours. This approach may contribute to reinforcing social cohesion in destinations. However, although the tourism sector has recognized the need for-and has already implemented-sustainable initiatives, an accurate quantification and measurement of these practices' real impacts on global tourism's sustainability is not yet possible.

A recent report issued by the UNWTO infers that the solution to the phenomenon may involve reorienting toward good destination management as well as successfully addressing issues outside of the tourism sector [33] (p. 3). The report also points out another aspect of overtourism; namely "an unacceptable decrease of the quality of life of citizens and quality of visitors' experiences in a negative way" [33] (p. 5). Taking the negative effects of tourism on society and culture into account can mean acknowledging a loss of authenticity, a commodification of culture, a standardization of tourism supply, and so on. [81]. In light of such considerations, it will be important to follow Butler's suggestions in order to reduce such pressures with the creation of new and alternative destinations, or to improve the resilience of existing destinations [52].

\section{Limitations and Caveats}

It is very important to note this study's limitations. First, the academic literature on the specific subject of overtourism is very recent and, as yet, rather limited. In the future, the phenomenon will be investigated in more depth. Second, the causes of overtourism are not homogeneous. The complexity and usefulness of defining the parameters of the phenomenon from a theoretical perspective guarantee future studies. Future studies will benefit from greater debate among researchers. Third, it is necessary to better link theory to practice through not only case studies but also the tools (indicators) already defined in the literature concerning issues with environmental consequences. This research topic warrants broader exploration, as related effects may be larger in relative terms than those calculated for the hotel sector alone.

\section{Conclusions and Discussions}

According to Perkumiene and Pranskuniené [16], the analysis of the extant literature allows us to highlight how the term overtourism does not represent a new phenomenon, but rather is a marker with which we want to represent in literature a theme increasingly present in the debate concerning the different models of tourism development. Although this specific term has been intensively used for 
less than three years, the problem it concerns has been discussed among scientists over the last 40 years, and many world tourist destinations have long been dealing with this challenging phenomenon [16].

Furthermore, the term overtourism does not describe a single phenomenon but a multitude of phenomena that converge and overlap, expressing a new trend worthy of analysis. The multifaceted aspects of overtourism in the near future will become increasingly important, as the concept is closely linked to issues of sustainability, to the measurement of the impact that tourism has on territories and communities both in economic and social terms and to the spread and use of new technologies. Thus, this multifaceted term summarizes a state or condition that, over the years, has been created through to the coming together of numerous factors connected to one another and well described in the literature analyzed in this paper.

The expected growth in tourism to 1.8 billion people by 2030 will lead to greater concentrations of tourist flows in already visited destinations, with important consequences in terms of sustainability. Compounding this challenge is the ever-increasing loss of bargaining power by local administrations with the main (including low-cost) air carriers and the consequent increasing difficulty of managing incoming flows into territories.

Through our review, and according to Butler [52] with regard to future approaches, two main considerations emerge. First, the challenges and issues to be faced in 2030 are most likely to be those faced by tourism today, but probably with different emphases. For Butler, some may have been reduced in effect, with constraints being the most likely in that regard; others, such as environmental pressures in relation to climate change and overtourism, are likely to have increased in significance alongside their potentially negative effects on tourism. Broader safety and security issues are beyond the remit of the tourism sector to resolve, and the industry will remain at the mercy of belligerents until global and local peace can be established. The challenges and issues raised in connection with new destinations and alternative forms of tourism are unlikely to be very different from the ones faced today, certainly not by 2030, although in specific areas they may change considerably in response to political negotiations. While the way that we find out about places and how to get there will continue to change, and while the range of activities we engage in on holiday may both widen and diminish in popularity, overall, by 2030, the global face of tourism will be like that of its participants: altered around the edges and in a few key features, but still recognizable compared to today's form.

A final issue that, in the future, should assume increased importance as a response to the phenomenon described with the term overtourism is the need to educate the tourist or visitor. Specifically, educational approaches must take place with reference to the knowledge of the destination, its customs and traditions and with respect to the territories and communities that maintain them.

Author Contributions: Conceptualization, A.C., M.P., C.V. and A.A.; methodology, A.C. and C.V.; validation, A.C., M.P., C.V. and A.A.; formal analysis, A.C and C.V.; investigation, A.C.; resources, A.C. and A.A.; writing—original draft preparation, A.C., M.P., C.V. and A.A.; writing-review and editing, A.C.

Funding: This research received no external funding.

Acknowledgments: We would like to thank to the comments of three anonymous referees and editor Hank Liu for their engagement with and contributions to this article.

Conflicts of Interest: The authors declare no conflict of interest.

\section{References}

1. Butowski, L. Tourist sustainability of destination as a measure of its development. Curr. Issues Tour. 2019, 22, 1043-1061. [CrossRef]

2. Schneider, D. The Carrying Capacity Concept as a Planning Tool; American Planning Association: Chicago, IL, USA, 1978.

3. Kowalczyk, A. Turystyka Zrównowazóna; Wydawnictwo Naukowe PWN: Warszawa, Poland, 2010.

4. Capocchi, A. L'Azienda Turismo. Principi E Metodologie Economico-Aziendali; McGraw-Hill: Milano, Italy, 2012.

5. Wheeller, B. Sustaining the ego. J. Sustain. Tour. 1993, 1, 121-129. [CrossRef] 
6. Koens, K.; Postma, A.; Papp, B. Is Overtourism overused? understanding the impact of tourism in a city context. Sustainability 2018, 10, 4384. [CrossRef]

7. Świąder, M. The implementation of the concept of environmental carrying capacity into spatial management of cities: A review. Manag. Environ. Qual. Int. J. 2018, 29, 1059-1074. [CrossRef]

8. Croce, V. With growth comes accountability: Could a leisure activity turn into a driver for sustainable growth? J. Tour. Futures 2018, 4, 218-232. [CrossRef]

9. Croce, V. Can tourism confidence index improve tourism demand forecasts? J. Tour. Futures 2016, 2, 6-21. [CrossRef]

10. Tosun, C. Challenges of sustainable tourism development in the developing world: The case of Turkey. Tour. Manag. 2001, 22, 289-303. [CrossRef]

11. Coca-Stefaniak, A.; Morrison, A.M.; Liu, C.; Pearce, D.G.; Stepchenkova, S.; Richards, G.W.; So, A.; Heeley, J.; Puczkó, L.; Shen, H.; et al. Editorial. Int. J. Tour. Cities 2016, 2, 273-280. [CrossRef]

12. Goodwin, H. The Challenge of Overtourism, Responsible Tourism Partnership Working Paper 4, October 2017. Available online: http://haroldgoodwin.info/pubs/RTP \T1\textquoterightWP4Overtourism01\T1\ textquoteright2017.pdf (accessed on 10 April 2019).

13. Gonzalez, V.M.; Coromina, L.; Galí, N. Overtourism: Residents' perceptions of tourism impact as an indicator of resident social carrying capacity - Case study of a Spanish heritage town. Tour. Rev. 2018, 73, 277-296. [CrossRef]

14. Scheyvens, R. Pro-Poor Tourism: Is there value beyond the rhetoric? Tour. Recreat. Res. 2009, 34, 191-196. [CrossRef]

15. Harrison, D. Pro-poor Tourism: A critique. Third World Q. 2008, 29, 851-868. [CrossRef]

16. Perkumiene, D.; Pranskuniene, R. Overtourism: Between the right to travel and residents' rights. Sustainability 2019, 11, 2138. [CrossRef]

17. Conrady, R.; Buck, M. Trends and Issues in Global Tourism 2009; Springer: Berlin/Heidelberg, Germany, 2009.

18. Steward, B. Writing a literature review. Br. J. Occup. Ther. 2004, 67, 495-500. [CrossRef]

19. Bolderston, A. Writing an Effective Literature Review. J. Med. Imaging Radiat. Sci. 2008, 39, 86-92. [CrossRef]

20. Fink, A. Conducting Research Literature Reviews: From the Internet to Paper, 2nd ed.; Sage Publications: Thousand Oaks, CA, USA, 2004.

21. Hernandez, S.A.; Cohen, J.; Garcia, H.L. Residents' attitudes towards an instant resort enclave. Anna. Tour. Res. 1996, 23, 755-779. [CrossRef]

22. Seraphin, H.; Sheeran, P.; Pilato, M. Over-tourism and the fall of Venice as a destination. J. Destin. Mark. Manag. 2018, 9, 374-376. [CrossRef]

23. Postma, A.; Schmuecker, D. Understanding and overcoming negative impacts of tourism in city destinations: Conceptual model and strategic framework. J. Tour. Futures 2017, 3, 144-156. [CrossRef]

24. Markusen, A. Fuzzy Concepts, Scanty Evidence, Policy Distance: The Case for Rigour and Policy Relevance. Critical Regional Studies. Reg. Stud. 2003, 37, 701-717. [CrossRef]

25. Van der Borg, J.; Costa, P.; Gotti, G. Tourism in European heritage cities. Ann. Tour. Res. 1996, 23, $306-321$. [CrossRef]

26. Rosenow, J.E.; Pulsipher, G.L. Tourism the Good, the Bad, and the Ugly; Media Productions \& Marketing: Lincoln, NE, USA, 1979; p. 264.

27. Baretje, R.; Defert, P. Aspects Economiques du Tourisme; Berger-Levrault: Paris, France, 1972.

28. Charvat, J.; Cerny, B. Untraditionelle Elemente bei der Erfassung der Fermdenverkehrsintensitat. Z. Fremdenverk. 1960, 3.

29. Menges, G. Methoden und Probleme der Deutschen Fremdenverkehrsstatistik; Schriftenreihe des Instituts fur Fremdenverkehrswissenschaft; Goethe Uniwersitaet: Frankfurt, Germany, 1955.

30. Kowalczyk, A. Geografia Turyzmu/Geography of Tourism; PWN Publishers: Warsaw, Poland, 2002.

31. Warszyńska, J.; Jackowski, A. Podstawy Geografii Turyzmu/Basics in Tourism Geography; PWN Publishers: Warsaw, Poland, 1978.

32. Lijewski, T.; Mikułowski, B.; Wyrzykowski, J. Geografia Turystyki Polski/Geography of Polish Tourism; PWE Publishers: Warsaw, Poland, 2008.

33. UNWTO. Overtourism? Understanding and Managing Urban Tourism Growth beyond Perceptions; UNWTO: Madrid, Spain, 2018. 
34. Freytag, T.; Bauder, M. Bottom-up touristification and urban transformations in Paris. Tour. Geogr. 2018, 20, 443-460. [CrossRef]

35. Shoval, N. Urban planning and tourism in European cities. Tour. Geogr. 2018, 20, 371-376. [CrossRef]

36. Casagrande, M. Heritage, tourism, and demography in the island city of Venice: Depopulation and heritagisation. Urban Island Stud. 2016, 2, 121-141.

37. Benner, M. From overtourism to sustainability: A research agenda for qualitative tourism development in the Adriatic, Heidelberg University. MPRA Paper No 92213. 2019. Available online: https://mpra.ub.unimuenchen.de/92213/ (accessed on 10 April 2019).

38. Meadows, D.H.; Meadows, D.L.; Randers, J.; Behrens, W.W. The Limits to Growth: A Report for the Club of Rome's Project on the Predicament of Mankind; Universe Books: New York, NY, USA, 1972.

39. Lawton, T.C. Cleared for Take-Off: Structure and Strategy in the Low Fare Airline Business; Routledge: London, UK, 2017.

40. Guttentag, D. Airbnb: Disruptive innovation and the rise of an informal tourism accommodation sector. Curr. Issues Tour. 2015, 18, 1192-1217. [CrossRef]

41. Gutierrez, J.; Garcia-Palomares, J.C.; Romanillos, G.; Salas-Olmedo, M.H. The eruption of Airbnb in tourist cities: Comparing spatial patterns of hotels and peer-to-peer accommodation in Barcelona. Tour. Manag. 2017, A 62, 278-291. [CrossRef]

42. Gutiérrez-Taño, D.; Garau-Vadell, J.B.; Díaz-Armas, R.J. The Influence of Knowledge on Residents' Perceptions of the Impacts of Overtourism in P2P Accommodation Rental. Sustainability 2019, 11, 1043. [CrossRef]

43. Veiga, C.; Santos, M.C.; Águas, P.; Santos, J.A.C. Sustainability as a key driver to address challenges. Worldw. Hosp. Tour. Themes 2018, 10, 662-673. [CrossRef]

44. Artal-Tur, A.; Briones-Peñalver, A.J.; Villena-Navarro, M. Tourism, cultural activities and sustainability in the spanish mediterranean regions: A probit approach. Tour. Manag. Stud. 2018, 14, 7-18. [CrossRef]

45. Francis, J. Overtourism. What is It and How Can We Avoid It? 2018. Available online: www.responsibletravel. com/copy/what-is-overtourism (accessed on 10 April 2019).

46. Milano, C. Overtourism and Tourismphobia: Global Trends and Local Contexts; Ostelea School of Tourism and Hospitality: Barcelona, Spain, 2017.

47. Novy, J.; Colomb, C. Urban tourism and its discontents: An introduction. In Protest and Resistance in the Tourist City; Colomb, C., Novy, J., Eds.; Routledge: London, UK; Taylor \& Francis: New York, NY, USA, 2016; pp. 1-30.

48. Araoz, G. Preserving heritage places under a new paradigm. J. Cult. Heritage Manag. Sustain. Dev. 2011, 1, $55-60$.

49. Oklevik, O.; Gössling, S.; Hall, C.M.; Jacobsen, J.K.S.; Grøtte, I.P.; McCabe, S. Overtourism, optimisation, and destination performance indicators: A case study of activities in Fjord Norway. J. Sustain. Tour. 2019, 1-21. [CrossRef]

50. Turner, L.; Ash, J. The "Golden Hordes": International Tourism and the Pleasure Periphery; Constable Limited: London, UK, 1975.

51. Ward, C.; Berno, T. Beyond social exchange theory: Attitudes toward tourists. Ann. Tour. Res. 2011, 38, 1556-1569. [CrossRef]

52. Butler, R.W. Challenges and opportunities. Worldw. Hosp. Tour. Themes 2018, 10, 635-641. [CrossRef]

53. Volgger, M.; Huang, S.S. Scoping irresponsible behaviour in hospitality and tourism: Widening the perspective of CSR. Int. J. Contemp. Hosp. Manag. 2019. [CrossRef]

54. Colomb, C.; Novy, J. Protest and Resistance in the Tourist City; Routledge: London, UK, 2016.

55. Volgger, M. The end of tourism through localhood and overtourism? An exploration of current destination governance challenges. In Tourismus Und Lebensraum. Perspektiven Für Alpine Destinationen; Pechlaner, H., Ed.; Springer: New York, NY, USA, 2018.

56. Ram, Y.; Hall, C.M. Walking tourism in cities: Introducing the special issue. Int. J. Tour. Cities 2018, 4, $281-284$. [CrossRef]

57. Oskam, J.; Boswijk, A. Airbnb: The future of networked hospitality businesses. J. Tour. Futures 2016, 2, $22-42$. [CrossRef]

58. Papathanassis, A. Over-Tourism and Anti-Tourist Sentiment: An Exploratory Analysis and Discussion, “Ovidius" University Annals. Econ. Sci. Ser. 2017, XVII, 288-293. 
59. Butler, R.W. The concept of a tourist area cycle of evolution: Implications for management of resources. Can. Geogr. 1980, 24, 5-12. [CrossRef]

60. Costa, J.; Carvalho, S.; Rodrigues, D. Portuguese tourism: How to share success? Worldw. Hosp. Tour. Themes 2018, 10, 705-711. [CrossRef]

61. IPDT, IPDT Tourism'18, Annual Tourism Trends Review; IPDT-Institute of Tourism: Zanzibar, Tanzania, 2018.

62. Chaperon, S. Tourism in contemporary cities: 6th ITSA Biennial Conference. Int. J. Tour. Cities 2017, 3, 321-323. [CrossRef]

63. United Nations Department of Economic and Social Affairs. The World's Cities in 2016-Data Booklet (ST/ESA/SER.A/392); United Nations: Geneva, Switzerland, 2016.

64. Novy, J. Urban tourism as a bone of contention. Four explanatory hypotheses and a caveat. Int. J. Tour. Cities 2019, 5, 63-74. [CrossRef]

65. Marais, L.; Nel, E.; Donaldson, R. Secondary Cities and Development; Routledge: London, UK, 2016.

66. DCMS. Government Tourism Policy; Department for Culture Media and Sport: London, UK, 2011.

67. Kennell, J.; Chaperon, S. Analysis of the UK Government's 2011 tourism policy. Cult. Trends 2013, 22, 278-284. [CrossRef]

68. Martín, J.M.; Martínez, J.M.G.; Fernández, J.A.S. An Analysis of the Factors behind the Citizen's Attitude of Rejection towards Tourism in a Context of Overtourism and Economic Dependence on this activity. Sustainability 2018, 10, 2851. [CrossRef]

69. Gonzalez, A.T. Venice: The problem of overtourism and the impact of cruises. Investig. Reg. J. Reg. Res. 2018, 42, 35-51.

70. Valcárcel, M. Y si muriese Venecia? ABC Cultural, 2 June 2018; 14-15.

71. Testa, S. E le Chiamano Navi; Corte del Fontego editore: Venice, Italy, 2011.

72. Settis, S. Se Venezia Muore; Giulio Einaudi editore: Torino, Italy, 2014.

73. Panayiotopoulos, A.; Pisano, C. Overtourism dystopias and socialist utopias: Towards an urban armature for Dubrovnik. Tour. Plan. Dev. 2019, 16. [CrossRef]

74. Rangus, M.; Bozinovski, B.; Brumen, B. Chapter 13-Overtourism and the green policy of Slovenian Tourism. In Responsible Hospitality: Inclusive, Active, Green; Gorenak, M., Trdina, A., Eds.; University of Maribor Press: Maribor, Slovenia, 2018.

75. Moscarda, G. The Role of Knowledge in Good Governance for Tourism. In Tourist Destination Governance: Practices, Theory and Issues; Laws, E., Agrusa, J., Richins, H., Eds.; CAB International: Wallingford, UK, 2011; pp. 67-80.

76. Cardoso, C.; Silva, M. Residents' perceptions and attitudes towards future tourism development: A challenge for tourism planners. Worldw. Hosp. Tour. Themes 2018, 10, 688-697. [CrossRef]

77. Costa, J.; Montenegro, M.; Gomes, J. Challenges and opportunities-lessons from destinations and organizations. Worldw. Hosp. Tour. Themes 2018, 10, 745-748. [CrossRef]

78. Pforr, C.; Pechlaner, H.; Volgger, M.; Thompso, G. Overcoming the Limits to Change and Adapting to Future Challenges: Governing the Transformation of Destination Networks in Western Australia. J. Travel Res. 2014, 53, 760-777. [CrossRef]

79. World Economic Forum. Wish You Weren't Here: What Can We Do About Over-Tourism? 2017. Available online: https://www.weforum.org/agenda/2017/09/what-can-we-do-about-overtouris (accessed on 10 April 2019).

80. UN World Tourism Organization (UNWTO). Yearbook of Tourism Statistics; UN World Tourism Organization (UNWTO): Madrid, Spain, 2017.

81. Reisinger, Y. International Tourism: Cultures and Behaviours; Elsevier: Oxford, UK, 2017.

(C) 2019 by the authors. Licensee MDPI, Basel, Switzerland. This article is an open access article distributed under the terms and conditions of the Creative Commons Attribution (CC BY) license (http://creativecommons.org/licenses/by/4.0/). 